\title{
Web 2.0 services and organization of interactive distance learning of a foreign language
}

\author{
Ekaterina Shugaeva ${ }^{1 *}$, Svetlana Bogatyreva $^{1}$, Serafima Shumakova ${ }^{1}$, and Irina Sinitsyna ${ }^{1}$ \\ ${ }^{1}$ Moscow State University of Technology and Management named after K.G Razumovsky, \\ Department of Foreign Languages, Moscow, Russia
}

\begin{abstract}
The issue of distance learning is very important at present. Herewith, learning of a foreign language is practically oriented, which causes difficulties upon conversion to distance learning. The main tool of implementation of distance learning is the use of information and communication technologies (ICT). The use of these technologies for educational targets is not a novelty, though, under conditions of distance learning, the ICT is nearly the only tool to organize learning. This article is devoted to the analysis of potentials of WEB 2.0 services for learning of a foreign language. The study is aimed at revealing possibilities to apply WEB 2.0 services for efficient implementation of interactive forms of learning of a foreign language in distance mode. The formulated target was achieved using the following methods: continuous sampling method for collection of actual material; comparative method to compare functionality of WEB 2.0 services and demands for implementation of interactive forms of learning. Generalization and systematization were selected to reveal the types of WEB 2.0 services. During the studies the types of WEB 2.0 services have been revealed characterized by the highest potential to implement interactive forms of learning. Among these types, the highest potential is demonstrated by the services for meetings and universal services; field-specific services allow to create jointly various types of content for further use during online meetings and for interaction on universal services. The novelty of the obtained results has ben stipulated by specificity of analysis criterion: the educational potential of WEB 2.0 services was studied not in whole but exactly for implementation of interactive forms of learning of a foreign language in distance mode.
\end{abstract}

Keywords: distance learning, interactive communication, fields of computer application in education.

\section{Introduction}

As a consequence of society informatization, the existing education system is characterized by situation when the established methods, skills and forms of learning require for reinterpretation, correction, and new pedagogical approaches [1]. Implementation and wide use of information and communication technologies (ICT) make them important for education, including learning of a foreign language.

* Corresponding author: chougaeva@mail.ru 
ICT are the technologies based on computers and telecommunication means for collection, storage, processing and transfer of data aiming at rapid and efficient operations [2]. According to the dictionary of pedagogical use, ICT are a combination of tools and methods of conversion of data aiming at obtaining of information of new quality (information product) [3].

WEB 2.0 is a modern concept of Internet development based on social services (blogs, communities, chats and forums, joint distance work with open content). Their main peculiarity is in organization of interaction among the users of service in the form of public exchange with data resources (text messages, photos, video fragments, and others), joint assessment and marking of content [4].

The importance of these technologies is in possibility to improve potential of education, including in distance mode. The main advantages of WEB 2.0 are:

1. Socialization,

2. Cooperation,

3. Creativity,

4. Reliability,

5. Common use [5].

This work is aimed at analysis of WEB 2.0 services, detection of possibilities to use them for efficient implementation of interactive forms of learning a foreign language in distance mode. The interactive approach assumes interaction between students and teacher; this is a joint process of cognition, where knowledge is acquired in joint activities by means of dialogue and polylogue of students between themselves and teacher [6]; learning is based on direct interaction of students with learning environment. Learning environment acts as reality, where the participants detect for themselves the region of acquired experience [7]. The features of implementation of interactive approach in learning of a foreign language were analyzed in sufficient details [8-10]; however, its implementation not in classes but in distance mode is characterized by significant distinctions. It becomes necessary to reinterpret practical implementation of interactive learning, mainly by means of ICT. Under conditions of distance learning, the ICT become not an integrated element of learning tools but, in fact, the only available tool. Therefore, the novelty of the research is in studying and comparison of possibilities to use WEB 2.0 services for efficient implementation of interactive forms of learning of a foreign language exactly in distance mode. The research hypothesis is as follows: analysis of WEB 2.0 services aiming at detection of possibility of their use for organization of distance interactive learning of a foreign language would allow to determine the types of services characterized by high potential in this field. The following targets were formulated to achieve the objective of the work:

1.to analyze the most popular WEB 2.0 services, to reveal their main functions,

2.to compare functionality of WEB 2.0 services and demands for implementation of interactive forms of learning,

3.to reveal the types of WEB 2.0 services characterized by high potential for implementation of interactive forms of learning of foreign languages in distance mode.

\section{Methods}

The continuous sampling method was applied for collection of actual material. 266 sites were sampled and analyzed, being characterized by potentials for learning of a foreign language. The comparative method was used for comparison of functionality of WEB 2.0 services and demands for implementation of interactive forms of learning. The types of WEB 2.0 services, characterized by high potential for implementation of interactive forms of learning of a foreign language in distance mode, were revealed by generalization and systematization. 


\section{Results}

The WEB 2.0 services, characterized by high potential for implementation of interactive forms of learning of a foreign language in distance mode, were determined on the basis of the analysis. The selected WEB 2.0 services were subdivided into main types depending on their functionality. The opportunities of each type were analyzed. The results are summarized in Table.

Table 1. Main types of WEB 2.0 services, their functionality and possibilities of use.

\begin{tabular}{|c|c|c|}
\hline $\begin{array}{c}\text { Type of WEB } 2.0 \\
\text { services }\end{array}$ & Functionality & $\begin{array}{c}\text { Possibility of use for implementation } \\
\text { of interactive forms of organization } \\
\text { of distance learning of a foreign } \\
\text { language }\end{array}$ \\
\hline $\begin{array}{l}\text { Services for creation } \\
\text { and/or storage of } \\
\text { documents }\end{array}$ & $\begin{array}{l}\text { Individually created texts: } \\
\text { uploading, storage, } \\
\text { common access. } \\
\text { Joint creation of texts. }\end{array}$ & $\begin{array}{l}\text { Individual creation of texts for further } \\
\text { joint reading, exchange, discussion; } \\
\text { joint writing of common connected text }\end{array}$ \\
\hline $\begin{array}{l}\text { Services for creation } \\
\text { and/or storage of } \\
\text { presentations }\end{array}$ & $\begin{array}{l}\text { Individually created } \\
\text { presentations: uploading, } \\
\text { storage, common access. } \\
\text { Joint creation of } \\
\text { presentations. }\end{array}$ & $\begin{array}{l}\text { Individual creation of presentations for } \\
\text { further joint reading, exchange, } \\
\text { discussion; joint creation and use of } \\
\text { presentations }\end{array}$ \\
\hline $\begin{array}{l}\text { Services for creation } \\
\text { of surveys and tests }\end{array}$ & $\begin{array}{l}\text { Passing: ready surveys and } \\
\text { tests; tests created by } \\
\text { teacher and/or students }\end{array}$ & $\begin{array}{l}\text { Joint creation, passing of surveys and } \\
\text { tests; discussion of results }\end{array}$ \\
\hline $\begin{array}{l}\text { Services for creation } \\
\text { of didactic games }\end{array}$ & $\begin{array}{l}\text { Ready didactic games; } \\
\text { creation of games by } \\
\text { teacher and/or students }\end{array}$ & $\begin{array}{c}\text { Joint creation, exchange, passing, } \\
\text { competition, discussion of process and } \\
\text { results }\end{array}$ \\
\hline $\begin{array}{l}\text { Services for creation } \\
\text { of mind maps }\end{array}$ & $\begin{array}{l}\text { Development of mind } \\
\text { maps; generation of word } \\
\text { cloud }\end{array}$ & $\begin{array}{l}\text { Joint creation of mind maps, working } \\
\text { with generator of word cloud on the } \\
\text { basis of students' survey, texts created } \\
\text { by them, joint discussion of results }\end{array}$ \\
\hline $\begin{array}{l}\text { Services for storage } \\
\text { of video }\end{array}$ & $\begin{array}{l}\text { Video uploading, storage, } \\
\text { exchange }\end{array}$ & $\begin{array}{c}\text { Creation of videos for common access, } \\
\text { discussion }\end{array}$ \\
\hline $\begin{array}{l}\text { Services for photos } \\
\text { and slides }\end{array}$ & $\begin{array}{l}\text { Image uploading, storage, } \\
\text { exchange }\end{array}$ & $\begin{array}{l}\text { Creation/selection of images for } \\
\text { common access, discussion }\end{array}$ \\
\hline $\begin{array}{l}\text { Services for creation } \\
\text { of blogs }\end{array}$ & Creation of blog & $\begin{array}{l}\text { Creation of blogs: statement of } \\
\text { judgements, exchange with opinions } \\
\text { and new information }\end{array}$ \\
\hline $\begin{array}{l}\text { Services for creation } \\
\text { of wiki-walls, virtual } \\
\text { boards }\end{array}$ & $\begin{array}{l}\text { Creation of page available } \\
\text { for user group, opportunity } \\
\text { to fill content by all } \\
\text { participants }\end{array}$ & $\begin{array}{c}\text { Joint filling of wall with content: texts, } \\
\text { notes, images, audio, video, links to } \\
\text { external sources, comments, } \\
\text { assessments }\end{array}$ \\
\hline $\begin{array}{l}\text { Services-social } \\
\text { networks }\end{array}$ & $\begin{array}{l}\text { Creation of education- } \\
\text { oriented groups, } \\
\text { communities in social } \\
\text { networks }\end{array}$ & $\begin{array}{l}\text { Joint filling of wall with content: texts, } \\
\text { notes, images, audio, video, links to } \\
\text { external sources; wide opportunities for } \\
\text { discussion, comments to materials, } \\
\text { assessment, chats }\end{array}$ \\
\hline $\begin{array}{l}\text { Services for } \\
\text { meetings, } \\
\text { conferences }\end{array}$ & $\begin{array}{l}\text { Organization of video } \\
\text { communication }\end{array}$ & $\begin{array}{l}\text { Joint oral communication, arrangement } \\
\text { of discussions, reports; oral } \\
\text { presentation and discussion of projects }\end{array}$ \\
\hline
\end{tabular}




\section{Discussion}

The obtained results have confirmed the opportunity to use WEB 2.0 services for education, this was mentioned by numerous researchers [11-16].

Among all the existing typologies and lists of WEB 2.0 services applied for education (for classes, for independent work [17-19]), the types of services detected in this work were formed with consideration for possibilities of their use exactly for organization of interactive forms of learning of a foreign language in distance mode.

The undisputable advantage of WEB 2.0 services during distance learning is possibility to organize distance interaction of participants.

Other advantages are as follows:

- accessibility of WEB 2.0 services (most of them are free, some are free with certain limitation of functionality),

- simple use (only an Internet browser is required to use the services),

- environment of social networks, blogs, videos, slideshows, presentations, online games, etc. comfortable for young people,

- possibility of practical application of a foreign language in real satiations,

- possibility of control, self-control, and mutual control of join activities of students,

- development of independence, creativity.

The most significant disadvantage of WEB 2.0 services is impossibility to completely substitute real life communication. However, this disadvantage is not relevant in the frames of this study, since the initially predetermined criterion was learning in distance mode. Partially this drawback can be compensated by the use of services for meetings, conferences.

Among the disadvantages of WEB 2.0 services revealed during this study, it is possible to mention limited functionality of many types of services for one type of working material (documents, presentations, surveys and tests, games, mind maps, videos, photos, blogs). This drawback can be eliminated by the following types of services: services for creation of wikipapers, virtual dashboards, social networks. Functionality of these services allows to combine various types of content created by means of field-specific services.

\section{Conclusion}

Implementation and wide-scale use of ICT, popularity and availability of Internet, the concept of WEB 2.0 - all these factors have exerted the influence on content and organization of learning, including learning of a foreign language. Under the conditions of distance learning, the ICT are, in fact, the only available tool of learning. Therefore, a promising trend in studying the features of WEB 2.0 services is analysis of their potential use exactly in distance mode. Since the main disadvantage of distance learning is limited interaction of students, the WEB 2.0 services were analyzed on the basis of criterion of their potential upon organization of interactive forms of learning. Field-specific services intended for working with certain type of material, and universal services allowing to combine different types of material should be highlighted. The services for meetings, conferences should be mentioned separately, since they promote online personal communication and interaction. Respectively, it can be concluded that the services for meetings and universal services possess high potential for organization of interactive forms of learning of foreign languages in distance mode; however, field-specific services allow to create jointly various types of content for further use during online meetings and for exchange and interaction on universal services.

Further analysis of WEB 2.0 services for organization of interactive forms of distance learning of foreign languages is possible on the basis of detailed analysis of certain types of WEB 2.0 services, as well as detailed analysis of possibilities and limitations related with age peculiarities of students. 


\section{References}

1. Ye.V. Timofeeva, Yu.A. Kail, Izvestiya AltGU, 2(82), 77-80 (2014)

2. A.V. Polshchikov, Rossiyskiy sledovatel, 16, 33-35 (2010)

3. L.M. Luzina (Ed.), Dictionary of pedagogical use (PSPI, Pskov, 2003)

4. L.A. Grinevich, MNKO, 2(45), 194-196 (2014)

5. N. Peachey, Web 2.0 tools for teachers (PeacheyPublications Ltd, Chatham, n.d.). Accessed on: December 20, 2020. [Online]. Available: https://www.scribd.com/doc/19576895/Web-2-0-Tools-for-Teachers

6. Z.N. Kodzova, Bulletin of the Maikop State Technological University, 4, 73-79 (2018)

7. M.V. Klarin, Pedagogy, 7, 12-18 (2000).

8. L.N. Golub, An interactive approach to competence-based teaching of foreign languages, in Proceedings of the 6th international scientific and practical conference "Issues of modern philology and problems of the methodology of teaching languages", 12-13 October 2018, Bryansk, Russia, 181-186 (2018)

9. V.A. Sarmandeeva, Nauchnyy vestnik Gumanitarno-sotsialnogo instituta, 9, 6 (2019)

10. Ye.Ye. Oreshina, T.V. Loginina, D.V. Makhovikova, An interactive approach to teaching a foreign language, in the Proceedings of the All-Russian scientific and practical conference with international participation "Pedagogy, psychology, society: topical issues", 29 February 2020, Cheboksary, Russia, 97-99 (2020)

11. L.A. Pavlenchekova, Obrazovaniye i problemy razvitiya obshchestva, 1(3), 20-23 (2017)

12. A.M. Klyoster, Teaching a foreign language using WEB 2.0 tools, in Proceedings of the I International Internet Conference of Young Scientists "Information technologies in the research space of multistructural languages", 5 December 2016, Kazan, Russia, 119-120 (2017)

13. N.Ye. Trushnikova, Using educational Web-resources in the process of teaching foreign languages, in Proceedings of the X International Scientific and Practical Conference: in 3 parts, 20 May 2017, Penza, Russia, 173-176 (2017)

14. T.V. Kovalyonok, T.S. Sazonova, Use of WEB 2.0 technologies in teaching foreign languages, in Proceedings of the XI International Scientific Conference dedicated to the 96th anniversary of the formation of the Belarusian State University, Intercultural communication and professionally oriented teaching of foreign languages, 219-220 (2017)

15. S. Alsaif, A.S Li, B. Soh, S. Alraddady, Procedia Computer Science, 161, 493-501 (2019). https://doi.org/10.1016/j.procs.2019.11.149

16. R.T. Kompen, P. Edirisingha, X. Canaleta, M. Alsina, J. M. Monguet, Telematics and Informatics, 38, 194-206 (2019). https://doi.org/10.1016/j.tele.2018.10.003

17. D.Yu. Medvedeva, Ye.N. Grigorieva, The use of WEB 2.0 technologies in teaching English grammar, in Questions of linguodidactics and translation studies. Collection of scientific articles, 88-92 (Chuvash State Pedagogical University named after I.Ya. Yakovleva, Cheboksary, 2017)

18. A.M. Musalayeva, A.Sh. Bakhmudova, Uralskiy nauchnyy vestnik, 12(3), 76-78 (2018)

19. R. Godwin-Jones, Language Learning \& Technology, (12)2, 7-12 (2008).

http://dx.doi.org/10125/44138 